\title{
Proteinet CCN2 beskytter hjertemuskelceller
}

\section{Proteinet CCN2 kan beskytte hjertemuskelceller mot skade forårsaket av oksygenmangel og redusere størrelsen på hjerteinfarkt i isolerte musehjerter.}

Proteinet CCN2 kan bli produsert i de fleste vev i kroppen og er høyt uttrykt i hjertet i fosterlivet, men produseres kun i små mengder i voksne, friske hjerter. Mengden av CCN2 i hjertet øker imidlertid kraftig ved tilstander som hjerteinfarkt, hypertrofi og hjertesvikt. Proteinets virkning på hjertemuskulaturen er likevel fortsatt ukjent.

I mitt doktorgradsarbeid har jeg studert potensielle gunstige effekter av CCN2 $\mathrm{i}$ hjertet. Vi fant at dette proteinet økte hjertemuskelcellenes toleranse mot hypoksi-/reoksygeneringsskade og oksidativt stress via den intracellulære signalveien PI3-kinase/Akt/GSK-3 $\beta$, som også tidligere er beskrevet å beskytte hjertemuskelceller. CCN2 reduserte størrelsen på hjerteinfarkt betydelig (58\% versus $34 \%$ nekrotisk hjertevev, $\mathrm{p}<0,001$ ) når proteinet ble tilført etter iskemi $\mathrm{i}$ isolerte musehjerter som ble utsatt for simulert hjerteinfarkt. I tillegg reduserte $\mathrm{CCN} 2$ hypertrofi forårsaket av angiotensin II-stimulering eller strekk av hjertemuskelceller.

En mulig klinisk bruk av CCN2 kunne være som et farmakologisk middel for å redusere størrelsen på hjerteinfarktet, for eksempel ved at $\mathrm{CCN} 2$ gis lokalt i koronararterier i forbindelse med utblokking (PCI) av en tilstoppet arterie. Kunnskapen om den integrerte funksjonen til CCN2 i den intakte organismen hos mennesker er imidlertid fortsatt mangelfull.

Ingvild Tronstad Moe

intmoe@ous-hf.no

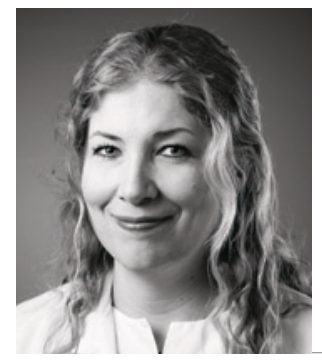

Ingvild Tronstad Moe. Foto: Kristin Ellefsen

\section{Disputas}

Ingvild Tronstad Moe disputerte for ph.d.graden ved Universitetet i Oslo 26.2. 2015. Tittelen på avhandlingen er Investigations on signaling pathways and functions of CCN2 in the heart.

\section{Rekanalisering ved akutt hjerneinfarkt}

\section{Intravenøs trombolytisk behandling ved hjerneinfarkt kan være trygt selv om det foreligger kontraindikasjoner. Effekten kan være avhengig av blant annet kroppstemperatur og røyking.}

Intravenøs trombolytisk behandling ved hjerneinfarkt for å oppnå rask rekanalisering har mange kontraindikasjoner, noe som begrenser behandlingsmulighetene. Forskning på bruken, sikkerheten og effekten av denne metoden er viktig for å oppnå en god behandling.

I doktorgradsarbeidet brukte vi et prospektivt slagregister med mer enn 2500 pasienter innlagt ved Nevrologisk avdeling, Haukeland universitetssykehus i perioden 2006-13 med hjerneinfarkt. Av pasientene som fikk trombolytisk behandling hadde halvparten kontraindikasjoner mot behandlingen. Metoden så imidlertid ut til å være trygg og effektiv selv om enkelte kontraindikasjoner forelå. Dette antyder at dagens kontraindikasjoner kan være for strenge, noe som bør undersøkes videre $\mathrm{i}$ fremtidige randomiserte studier.

Hos pasientene som fikk trombolytisk behandling fant vi en uavhengig assosiasjon mellom rask bedring av nevrologiske symptomer og en høyere kroppstemperatur ved innkomst. Dette tyder på at metoden er mer effektiv ved høyere kroppstemperaturer. Funnet kan forklare hvorfor man i studier ikke har funnet effekt av hypotermibehandling ved hjerneinfarkt.

I tillegg så vi en sammenheng mellom godt nevrologisk utfall ved utreise og røyking hos pasienter behandlet med trombolyse. Vi så ikke tilsvarende sammenheng hos pasientene med akutt infarkt som ikke fikk trombolytisk behandling. Dette kan tyde på at røykere har tromber som er bedre egnet for denne metoden sammenliknet med ikkerøykere.

\section{Christopher Elnan Kvistad} celnan@hotmail.com

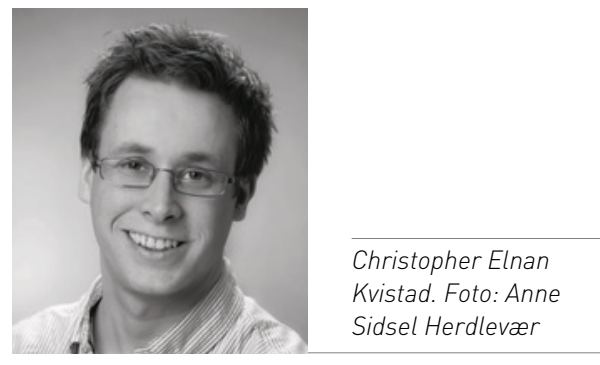

Disputas

Christopher Elnan Kvistad disputerte for ph.d.graden ved Universitetet i Bergen 20.2.2015. Tittelen på avhandlingen er Recanalization in cerebral ischemia - a register-based study. 